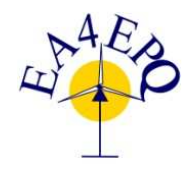

International Conference on Renewable Energies and Power Quality (ICREPQ'14) Cordoba (Spain), $8^{\text {th }}$ to $10^{\text {th }}$ April, 2014

Renewable Energy and Pourer Qualily. Fournal (RE\&PQJ)

ISSN 2172-038 X, No.12, April 2014

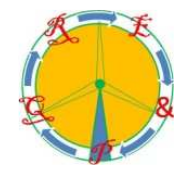

\title{
An overview on the Molise (Italy) renewable energy law: the conflict between the landscape protection and the territory management
}

\author{
Cialdea D., Quercio N. \\ Di.B.T. Department \\ Molise University \\ Via De Sanctis, 86100 Campobasso (Italy) \\ phone: +390874 404970, fax: +390874 404970 \\ e-mail: cialdea@unimol.it
}

\begin{abstract}
.
This paper is a study about the renewable energy in particular about the interventions on the land, or of the wind and photovoltaic plants.

The study area is the Molise Region in the south of Italy, which contains the greatest number of plants in relation to the whole national territory.

In Italy there is also a big difference between the regions in terms of the guidelines and the law-making control of the plants localization.

The study analyzes technical norms and suggests a new methodology that could support Local Authorities decisions.
\end{abstract}

\section{Key words:}

Renewable Energy, Legislation, Wind Power Energy, Landscape, Environment.

\section{The aims}

The aim of this study is mainly to draw up a cognitive framework of regional laws, analyzing in particular laws of the Molise Region, that have been enacted in recent years.

Following studies already carried out by our research group - including spatial analysis of knowledge of the land and its topography, its natural sites and its settlement systems - this paper describes an ongoing collaboration between our University of Molise, the Molise Region and the Regional Protection Heritage Office of Molise, for the verification of existing tools $[1,2]$, both from the restrictive perspective (imposition of the "constraint" that prevents the energy plants realization) and from the point of view of production (energy requirements).

In fact, in 2011, the Laboratory 1.a.co.s.t.a. (Director prof. D. Cialdea) of the University of Molise was engaged for the realization of the "New Regional Landscape Plan of Molise", through an agreement with the Molise Region.

\section{About Italian Renewable Energy Laws}

In 1991 National Laws no. 9 and no. 10 opened a new time in the production of electricity. From now, the energy production is no longer exclusive of ENEL (National Agency for Electricity). In particular, the Law no. 10/91 delegated Regions for the identification of suitable areas for the exploitation of renewable energy sources. Moreover, this Act recognizes the expropriation for public interest of the soil on which establishes systems for the production of electricity from renewable sources.

In 1999, implementing European Directive 96/92/EC (Common Rules For The Internal Market In Electricity), the Legislative Decree no. 79/99 promotes the production of electricity from renewable sources, forcing producers of energy from fossil fuels to enter in the market the clean energy or, alternatively, as determined by the Ministerial Decree of 11 November 1999, to purchase "green certificates". Following the reform of Title $\mathrm{V}$ of the Italian Constitution, the mayor legislative efficiency was assigned to Regions.

Moreover, the Legislative Decree no. 387/2003, from the European Directive 2001/77/EC on the production of electricity from renewable sources, has established the purpose of promotion of renewable energy sources. In particular, art. 12 ordered that the works for the construction of plants powered by renewable energy sources are of public utility and urgent and are subject to authorization only in accordance with the Regional Ministerial Guidelines. In implementing these guidelines, Regions can indicate areas and sites not suitable for the construction of specific types of plants.

Afterwards new Guidelines for renewable energy plants authorization were implemented by the National Decree in 2010: they will be analyzed in this paper. 


\subsection{The Molise Region case study}

The Molise Regional Environmental Energy Plan was approved in 2006 [3] with the objective to optimize and encourage energy conservation, and to enhance the clean energy sources with particular attention to the hydro-power and the wind-power.

The Energy Plan enhances the potential of Molise respect to the production of energy from wind and assumes, in the 2015 scenario, the installation of wind turbines for over 1,700 MW. In addition, it identifies as sites of great interest for wind energy areas within the Biferno river basin, the only river completely inside the Region.

This 2015 scenario completely ignores the contribution of photovoltaic plants connected to existing buildings, while it is not exactly considered the achievements of photovoltaic systems on the ground.

The Energy Plan sets out Regional Guidelines for the evaluation of projects; however impacts of wind farms will be implemented by successive regional laws.

In 2008 the Molise Region enacts a regional law [4] in order to govern localization of wind and photovoltaic settlements in its territory. The subsequent Resolution no. 167 [5] approves guidelines for the "unique act" for formal projects evaluation.

The Regional Law no. 15/2008, and therefore its subsequent guidelines, identifies a number of areas not suitable for the installation of wind and photovoltaic plants. In particular these areas are: regional parks and reserves, zones named 1 in national parks, areas of "full protection and preservation" of Territorial Landscape Plans, Special Protection Areas, Sites of Community Interest.

Moreover it includes a particular area that is the "Valley of the Tammaro River" with mountains that surround it.

It is necessary underline that this Law (Art. 2, paragraph 1) forbid the construction of wind farms even in the buffer zone of not less than $3 \mathrm{~km}$ from the perimeter of parks and archaeological areas, in the buffer zone of not less than $1 \mathrm{~km}$ from the urbanized perimeter, in the buffer zone of 500 meters from residential or rural houses, in the buffer zone of 200 meters from the perimeter boundary of the neighbouring municipalities, in the buffer zone of 5,000 linear meters from the coastline, in the buffer zone of $1 \mathrm{~km}$ from river shores, wetlands, lakes and dams.

In fact these points of paragraph 1 of article 2 were declared illegal by the Constitutional Court Judgment no. 282/2009 [6]: areas not suitable must be identified by the Region with the support of technical reasons.

This Judgment also declared that are forbidden wind offshore plants, because the administrative functions relating to the use of the maritime domain are entitled to the National State.

Article 3 was also declared illegal because it subordinated the permit granting to specific limits for wind plants (set in 545 wind turbines, each of the minimum power of $2 \mathrm{MW}$ ) and for photovoltaic systems on the ground (set in $500 \mathrm{MW}$ of total power).

Really at the same time, the Molise Region already was changing the regional norms: in fact the Regional Law 15/2008 was replaced with the Regional Law 22/2009 [7] and its new Guidelines [8].

This law takes into account emendation by the Constitutional Court Judgment and includes into the list of not suitable areas the Important Bird Areas and into the list of suitable areas the Sites of Community Interest (even if after successful completion of the Assessment Incidence Evaluation) and the "Valley of the Tammaro River" area, with mountains that surround it.

Moreover article 3 paragraph 1 of the Regional Law 22/2009 provides that plants - not exceeding $1 \mathrm{MW}$ - were authorized directly by Municipalities through the DIA ("Dichiarazione di Inizio Attività - Starting Construction Report").

Also in this case another Constitutional Court Judgment [9] stated that this exception would be introduced only by Ministerial decree and not directly by Municipalities; so the Molise Region amended its Guidelines stating that, even for systems not exceeding $1 \mathrm{MW}$, must follow the procedure for a single authorization issued by Regional Norms [10].

In 2010 further modifications and integrations appear in a new Regional Law [11]: in particular the "Valley of the Tammaro River" area is replaced into the list of not suitable areas, as one of the most important archaeological values context in the Molise Region.

Subsequently a Resolution of the Ministers Council [12] declares the unconstitutionality of this Regional because the already mentioned Legislative Decree no. 387/2003 provides that Regions can proceed to the identification of unsuitable areas, but in accordance with National Guidelines. In fact, according to D.M. 10/09/2010 (National Guidelines for the authorization of plants powered by renewable sources) not suitable zones could be identified with regard to specific sites after the completion of a thorough investigation that would identify specific areas particularly sensitive or vulnerable.

Finally the Molise Region approved last guidelines for authorization to build and to manage plants producing electricity from renewable sources [13], that reproduces verbatim the DM 10/09/2010. 


\subsection{A Comparison with neighbour Regions laws}

The Region of Apulia, and in particular the Province of Foggia (that is the area adjacent to the Molise Region), is the Italian Region with the highest production of electricity from wind power.

Even in this region the legislation about the renewable energy is in evolution.

In 2006 the first Regional Regulation [14] already shows a big difference compared with authorization procedures existing in Molise.

The Regulation introduces the Regulatory Plans for the installation of Wind Power Plants, that are drawn up by the Municipality and that contain the purpose of identifying areas that are not suitable for the location of wind turbines.

This tool, in accordance with the Regional Thematic Landscape Plan [15], already approved by the Regional Council in 2000, allowed a greater land-use planning attention, with regard to the location of the plants for renewable energy, although this has not managed to prevent a strong modification of the landscape especially in the "Capitanata area", near the Molise Region.

In 2010 a new Regulation implements national guidelines of the DM 10/09/2010, with attached list of areas and sites is not allowed the localization of specific types of plants from renewable energy sources [16]: these areas are National Protected Areas, Regional areas RAMSAR, SPA and IBA, UNESCO sites and areas and buildings protected by art. 142 of Legislative Decree no. 42/2004, risk areas in relation to their hydraulics and geomorphology conditions, areas named A and B in the Regional Thematic Landscape Plan (it means areas with exceptional and high relevance landscape value).

The most important think is that for the first time there is an attention paid to visual cones of primary importance for the conservation and the formation of the image of Apulia also in terms of reputation and international tourist attraction. New study in depth were added in the subsequent Regional Law [17] and its Regulation Norms [18].

The Abruzzo Region, on the other hand, issues its first Guidelines for the construction of plants for the production of energy from renewable sources in 2007 $[19,20]$.

In these guidelines two types of areas not suitable to the installation of these facilities are distinguished. The first category is for areas in which there is the absolute prohibition of installation, i.e. Zones A and B of National and Regional Parks, Nature Reserves and Protection Oasis, Wetlands, the Macro area A and $\mathrm{B}$ for safeguarding the Marsicano Bear, areas of migratory flyways, Archaeological Sites, areas classified as highly dangerous and a hydraulic safety zone of at least $500 \mathrm{~m}$ from urban areas.
The second category includes zones classified as Critical Areas, for which the authorization refers to the Environmental Assessment procedures.

There are areas next to hunting zones, areas close to caves, mountain passes, IBA, SCIs and SPAs (SPAs worth the absolute prohibition for wind power), corridors important bird areas and areas named $\mathrm{A}$ in the Regional Thematic Landscape Plan.

These guidelines were only partially integrated and / or modified [21,22,23], and they are still in force because it does not arise in non-conformity with the principles and criteria set out in DM September 10, 2010. It is worth underlying the relevance of the landscape planning acts even in the identifying areas that need particular attention for the implementation of energy plants.

\subsection{Critical Aspects in Molise Norms}

The Molise Regional Environmental Energy Plan failed to outline a new scenario for the development of the energy sector on the Molise territory.

The plan staked everything on the development of wind energy but without analyzing in detail the impact of these facilities in relation to their localization.

The late adoption of the first regional law in the field of renewable energy [4] with its sequential guidelines [5] and the Judgment that found it unconstitutional, contributed to the proliferation of wind farms in an unplanned way, creating significant impacts and modification of the landscape on the entire territory of the Region.

The Regional Law 15/2008 - and subsequent ones have only ever tried to prevent the wind or photovoltaic plants localization in special areas of the Region, without making a real wide-area planning tool, that could identify not only areas not suitable, but also particularly suitable areas because of presence of natural resource and because of their morphological characteristics ideal for the installation of these systems, minimizing their impact on the territory.

Emblematic is the case of "Valley of the Tammaro River", an area of considerable archaeological interest related to the presence of the ancient Roman city of Altilia. This area appears and disappears in the list of areas not suitable for the installation of renewable energy production systems without such a ban is supported by a concrete analysis.

Another negative factor, that stimulated the unplanned development of renewable energy, was the limited number of realizable plants in the Region, which created a race to the numerous projects presentation, without in-depth practicability studies, which congested Regional Offices, responsible for issuing permits for the construction of these plants. Another incentive to the 
proliferation of wind power was compensatory measures for Municipalities, purely economic, seen as a big help to the municipal funds deficit.

The Molise Region is especially lacking in wide-area planning. Both Molise Provinces, Campobasso and Isernia, do not have any Management Territorial Plans.

The only supra-municipal planning action is represented by Landscape Territorial Plans.

These plans, which actually do not cover the entire Region territory, aim to provide for Local Authorities a norms tool and regulatory framework capable of defining the convertibility of elements and/or parts of the territory in relation to qualitative and quantitative characteristics, connected to their natural, historical, cultural aspects.

\section{The Research Methodology and Expected Results}

Our research was then organized according to the following methodology for surveying the territory that could substantially support legislative strategies for the plants installation control.

Really, it was the activity realized in collaboration with the Molise Region in order to create the "New Regional Landscape Plan of Molise" that has enabled us to put a strong emphasis on interdisciplinary approach that characterizes the study of the energy plants location.

In particular, our work will examine the tormented history of Molise regional law.

Our research has allowed us to highlight the difficulties that arose from the recognition of the need for protection of numerous areas of the Region.

The National Legislation (and consequently also the Regional Legislation) for the protection of the landscape provides a great importance for the maintenance of landscape features (landscape characteristics on its various natural and anthropogenic components) in connection with the historical systems (historical centres, historical widespread buildings), agrarian landscapes (typical cultural landscape), weavings historical territorial, scenic routes and presence of areas to strong symbolic significance.

Our methodology is based on the reading of the territory intervisibility and it is realized through a comparison of different factors in a matrix.

Our final result is precisely the realization of this matrix, shared by the Molise Region and by the Regional Authority responsible for the Protection of Cultural Heritage and Landscape, in order to support the ongoing regional regulation.

\subsection{The Intervisibility Methodology by MIBAC}

Guidelines for wind power plants connection to the landscape, issued by MIBAC (MInistero per i Beni e le Attività Culturali - Ministry of Heritage and Culture Activities) in order to provide suggestions for plants design and their landscape evaluation [24], describe Visibility and Intervisibility Maps as useful instruments for plants control.

The Theoretical Intervisibility Map (MIT) propose to classify the area around the so-called "targets", it means wind turbines, in Visibility Types. Their diversification can emerge in a special thematic map (the Real Intervisibility Map) in which assign a colour according to the level of visibility from different points of observation. The percentage of visibility implant may be defined in function of the number of wind turbines visible compared to the total of those that must be made.

Additional information is provided by the MIT Visibility Map, overlapping Theoretical and Real Intervisibility Maps; in relation with each observation point, a synthetic index expresses the level of the plants impact.

This approach shows its limitations because it doesn't take into account factors connected to the land use characteristic. Moreover it suggests that the maximum distance for the Visibility Maps is $20 \mathrm{~km}$, but this parameter is not always valid for every morphological condition.

\subsection{A New Intervisibility Approach}

Our methodology aims to show how control and management of different landscapes can be transformed into control and management of the visual-cognitive relationship between landscape and observer.

However the perceptive control alone cannot be associated with a total control of the landscape but can become an important tool for monitoring transformations in particular areas of the territory: it also can be considered as useful tool in the territorial planning process. For this reason we consider the reciprocal visibility existing between diverse points in the territory in order to underline aspects characterising the landscapes and the elements of which it is composed.

First of all the perception of the landscape and its evolution are linked to the observation point and its distance. Therefore, to be part of the landscape means to seek its intrinsic characteristics with continuous jumps in scale which lead to a continuous tension between nearby and far off elements, between external and internal, action and contemplation.

Now we expose a synthesis of different factors. They are physical-psychological laws of visual perception and evaluation of historical, anthropological and cultural characteristics which can be found in a particular sector of territory, and specifically Visual Aspect and Cultural Aspect [25]. 
Therefore, perceptive analysis does not only involve visual perception, but also involves the mental processing which constitutes cultural perception, that is a cultural interpretation of what is seen.

The study area (that is in particular the portion of the Molise Region along the Adriatic Sea Coast) is made up of a series of elements which together form the image of the landscape. These elements have been synthesised into two large groups, Values and Detractors.

The valences are elements conferring value to the entire landscape system that may be different (such as architectural, naturalistic, historical elements). They have been divided into two groups: residual and naturalistic values. The first group comprises what remains of areas of great natural worth and are the historical memory of these places. They are: Common land; Residual of woods' areas; Residual of dunes areas; Residual areas of cattle-tracks.

The second group comprises those areas with the recognised presence of an element of great naturalistic worth that is the presence of particular species of flora and fauna. They are: Important Bird Areas (Important Bird Areas and Special Protection Zones at the sense of the Directive 79/409/EEC), Site of Community Importance (Site of Community Importance at the sense of the Directive 92/43/EEC "Habitat" adopted in Italy by the D.P.R. 357/1997), Special Protection Zones, Beaches free (Data are required by Plan for Use of State Coastal Property for Tourism and Leisure of Molise Region, Source: B.U.R.M. 12/2004), Areas restricted under law 1497/39, Areas restricted Ope Legis under law 431/85 [26].

However, if values highlight landscape qualities, detractors in some way penalize this system. The detractors list is not exhaustive; it has been prepared after a detailed territory reading with its typical land use features. They are:

$\begin{array}{ll}- & \text { Airport } \\ - & \text { Industrial Areas } \\ \text { - } & \text { Quarries } \\ \text { - } & \text { Purifiers } \\ \text { - } & \text { Landfill sites } \\ \text { - } & \text { Electrical Infrastructures } \\ \text { - } & \text { Wind farms } \\ - & \text { Rail networks } \\ \text { - } & \text { Photovoltaic Plants } \\ - & \text { Dewatering Pumps } \\ - & \text { Port } \\ - & \text { Gas turbines }\end{array}$

The analysis of visibility represents a very important tool in the analysis of a landscape context. This research looked at all of the identified detracting elements; however the case of the wind farms is emblematic.
Today the visual impact of the wind turbines is calculated, as already mentioned, with the simplified formula created by the Ministry of Heritage and Culture. Our research took as valid the data from the Ministerial guidelines, but also inserted the presence of other elements.

This Ministerian calculation, the aim of which is to establish at what distance a wind turbine can be perceived, has two basic limits. That is, it considers the territory to be uniform and does not take into consideration the elements, and their interrelationships, which are an integral part of the landscape. Therefore it can be means that the perceptive analysis is defined as a summarize between the analysis of visibility and of distance. The first one is directly correlated to the height of each single element and its geographical position (including height above sea level), while the second is correlated to the distance within which it is possible to perceive its presence. It is clear that, in the analysis of distance for each detractor, the distance from which it is possible to perceive it changes according to its nature. [27].

We undertook our analysis in ArcGis fiels: at the operational level the detractors have been represented through graphics primitives with its geographic coordinates. After that, we realized shapes for each detractor type, according to their specific spatial characteristics. The only geometric figure, with its spatial location, is a not sufficient element to realized visual impact analysis because the height of the detractor is a fundamental element: more the detractor is high and more visible is it from several observation points by modifying the landscape perception. Therefore, for each detractor type, was assigned an average height determined by a detailed investigation of different detractor's types. For wind farms, for example, each wind turbine was represented with a point datum. However, an areal datum were associated for solar panel installations. Only ground installations have been included as the other types form a single unit with the structures with which they are associated.

We used the Viewshed command which, from the point of view of data processing, corresponds to a grid in which each cell has a visibility value, and we converted polygonal data into point data. Thus, solar panel farms, quarries, landfill sites, water purification plants, water-scooping machine, other infrastructures (ports, airports), industrial areas and the gas turbogenerator resul as point datum [28].

First of all we realized that using only the Digital Elevation Model datum results were incertain as the detractors resulted as visible from numerous parts of the territory, when this is not the real situation.

We also realized that territory elements interfere with the visibility. These elements are not only of 
orographic origin. In fact, we have also wooded, industrial and urban areas. Therefore we correct the original datum of Digital Elevation Model using the Land Use datum, attributing them with the average height. From these data have been realized the two grid (distance and visibility) and then they were combined to form a final grid, where values are between 0 and 5 ( 0 corresponding to invisibility while 5 corresponds to maximum perception).

\section{Conclusions}

In this landscape vision system, we identified "values" and "detractors".

Analyses carried out from our research are: density analysis and analysis of the combined visibility and distance.

The calculation of the density of the detractors was carried out using a single data point of detractors (with appropriate conversions from linear and polygonal data point) to which was added an increasing weight.

For each detractor (in this case there is an example for wind farms in the coastal zone) type class we counted the number of points (Cnt_detrat); then we given the weight (Max_peso) with the function $1 /$ (number of detractors per class). Finally, we added a Corrective Factor (Correttivo) based on the importance of detractor.

\begin{tabular}{|l|c|c|c|}
\hline Detractor & Cnt_detrat & Max_Peso & Correttivo \\
\hline airport & 144 & 0,00694444444 & $0^{*}$ \\
\hline industrial areas & 799 & 0,00125156446 & 4 \\
\hline quarries & 382 & 0,00261780105 & 1 \\
\hline purifiers & 3 & 0,33333333333 & 0 \\
\hline landfills & 1 & 1,00000000000 & 5 \\
\hline electrical infrastructure & 3226 & 0,00030998140 & 3 \\
\hline wind farms & 51 & 0,01960784314 & 4 \\
\hline railway & 1840 & 0,00054347826 & 1 \\
\hline photovoltaic plants & 756 & 0,00132275132 & 2 \\
\hline dewatering pumps & 3 & 0,33333333333 & 0 \\
\hline port & 84 & 0,01190476190 & 0 \\
\hline roads & 8168 & 0,00012242899 & 2 \\
\hline gas turbine & 27 & 0,03703703704 & 5 \\
\hline
\end{tabular}

For the assessment of two different grids we realized the Grid visibility (directly related to the heights of the individual wind turbines and their geographical position and then to the portion above sea level) and the Grid distance (directly related to the distance within which it is possible to perceive the turbine presence.

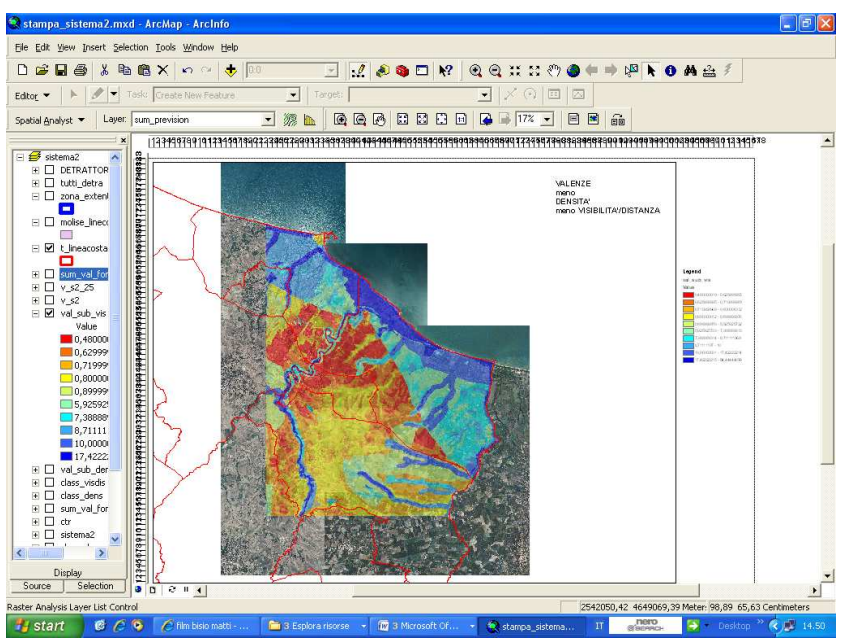

Fig. 1. The final grid for the sample area of the Coastal Molise Region

Our analytical approach, which is included in an larger landscape analysis, underline the importance of visual perception, in order to highlight areas in which already exists a detractors strong impact.

It could be really very useful in planning stage and in the policies determination for implantations of the renewable sources energy production.

Taking into account the landscape visibility during these implantations will be possible to choices more appropriate locations so that the alternative sources energy production (important for environmental protection) will not cause negative repercussions on portions of territory of high landscape quality.

Moreover this territorial analysis has universality and repeatability characters that make it applicable at all kinds of territory, unless changes related to the nature of places.

This experimental methodology is now in training of testing for the "New Regional Landscape Plan of Molise" and we would like to remark the possibility to use it to support planning decision. 


\section{References}

[1] Cialdea D., Maccarone A., Sollazzo A., "Wind energy and landscape in Molise - Legislation, Incentives and Problems" in Proceedings of the International Conference on Renewable Energies and Power Quality (ICREPQ'10) Granada (Spain), 23rd to 25th March, 2010 Paper n. 493, 2010

[2] Cialdea D., Maccarone A., Sollazzo A., "Wind energy in Molise. Guidelines for wind power farms in landscape" in Proceedings of V Worshop APDR Associação Portuguesa para o Desenvolvimento Regional, Casos de Desenvolvimento Regional, 08/02/2010 Universidad de Coimbra, Sessão 11 Paper 01037, 2010

[3] Delibera Consiglio Regionale Molise n. 117 del 10 luglio 2006 - Approvazione del Piano energetico-ambientale regionale

[4] Legge Regionale Molise 15 del 21 maggio 2008 - Disciplina degli insediamenti degli impianti eolici e fotovoltaici sul territorio della Regione Molise

[5] Delibera Consiglio Regionale Molise n. 167 del 10 giugno 2008 - Prime linee guida per lo svolgimento del procedimento unico di cui al comma 3 dell'articolo 12 del Decreto Legislativo n. 387/2003, relativo all'installazione di impianti per la produzione di energia elettrica da fonti rinnovabili sul territorio della regione Molise e per il corretto inserimento degli impianti nel paesaggio - Attuazione dell'atto consiliare n. 117 del 10 luglio 2006, recante: "Piano energetico ambientale - regionale"

[6] Sentenza della Corte Costituzionale n. 282/2009 del 2 novembre 2009

[7] Legge Regionale Molise 22 del 7 agosto 2009 - Nuova disciplina degli insediamenti degli impianti di produzione di energia elettrica da fonti rinnovabili nel territorio della Regione Molise

[8] Delibera Consiglio Regionale Molise n. 1074 del 16 novembre 2009 - Nuove Linee Guida

[9] Sentenza della Corte Costituzionale n. 194/2010 del 26 maggio 2010

[10] Delibera Giunta Regionale Molise n. 857 del 25 ottobre 2010 - Modifica alle linee guida per lo svolgimento del procedimento unico di cui all'art. 12, comma 3 del D.lgs 387/03, in materia di produzione dì energia elettrica da fonti rinnovabili.

[11] Legge Regionale Molise n. 23 del 23 dicembre 2010 Modifiche ed Integrazioni alla L.R. n. 22 del 7 agosto 2009

[12] Delibera Consiglio dei Ministri del 23 febbraio 2011 Impugnativa della legge n. 23 del 23 dicembre 2010

[13] Delibera Giunta Regionale Molise n. 621 del 4 agosto 2011 "Linee guida per lo svolgimento del procedimento unico di cui all'art. 12 del D. Lgs. n. 387/2003 per l'autorizzazione alla costruzione ed all'esercizio di impianti di produzione di energia elettrica da fonti rinnovabili sul territorio della Regione Molise"

[14] Regolamento Regionale Puglia 4 ottobre 2006, n. 16. "Regolamento per la realizzazione di impianti eolici nella Regione Puglia".

[15] Deliberazione Giunta Regionale Puglia n. 1748/2000 Approvazione del Piano Urbanistico Territoriale Tematico per il Paesaggio (PUTT/P)
[16] Regolamento attuativo del Decreto del Ministero per lo Sviluppo Economico del 10 settembre 2010: "Linee Guida per l'autorizzazione degli impianti alimentati da fonti rinnovabili", recante la individuazione di aree e siti non idonei alla installazione di specifiche tipologie di impianti alimentati da fonti rinnovabili nel territorio della Regione Puglia".

[17] Legge Regionale Puglia n. 25 del 24 settembre 2012: "Regolazione dell'uso dell'energia da fonti rinnovabili"

[18] Regolamento Regionale Puglia 30 novembre 2012, n. 29: "Modifiche urgenti, ai sensi dell'art. 44 comma 3 dello Statuto della Regione Puglia (L.R. 12 maggio 2004, n. 7), del Regolamento Regionale 30 dicembre 2010, n. 24 "Regolamento attuativo del Decreto del Ministero dello Sviluppo del 10 settembre 2010 Linee Guida per l'autorizzazione degli impianti alimentati da fonti rinnovabili, recante la individuazione di aree e siti non idonei alla installazione di specifiche tipologie di impianti alimentati da fonti rinnovabili nel territorio della Regione Puglia."

[19] Delibera Giunta Regionale Abruzzo 12 Aprile 2007, n. 351: Criteri e indirizzi per il rilascio dell'autorizzazione unica per la realizzazione di impianti di produzione di energia da fonti rinnovabili

[20] Delibera Giunta Regionale Abruzzo 754/07: "Linee guida atte a disciplinare la realizzazione e la valutazione di parchi eolici nel territorio abruzzese - Approvazione"

[21] Delibera Giunta Regionale Abruzzo n. 1032 del 29/12/2010: Attuazione delle Linee Guida per l'autorizzazione degli impianti alimentati da fonti rinnovabili di cui al D.M. $10 / 09 / 2010$

[22] Delibera Giunta Regionale Abruzzo 12 marzo 2012, n. 148: Linee Guida sulle aree non idonee all'eolico Adeguamento alle Linee Guida Nazionali

[23] Delibera Giunta Regionale Abruzzo n. 931 del 28/12/2012: Procedura Abilitativa Semplificata ai sensi dell'art.6 del D.Lgs. 03/03/2011 n. 28 - Criteri specifici

[24] di Bene A., Scazzosi L.. (edited by), Gli impianti eolici: suggerimenti per la progettazione e valutazione paesaggistica, Roma: Gangemi. (2006).

[25] AA.VV., Ecologia del paesaggio, Bari: GreenLab, 2008

[26] Cialdea D, A new landscape planning approach in areas with a strongly rural matrix. In: Campagna M., De Montis A., Isola F., Lai, S., Pira C., Zoppi C. (edited by). Planning Support Tools: Policy Analysis, Implementation and Evaluation. vol. CHAP 5, p. 453-464, MILANO: Franco Angeli, 2012

[27] Cialdea D, Sollazzo A., Visibility analysis for identifying detractors in rural areas. In: Campagna M., De Montis A., Isola F., Lai, S., Pira C., Zoppi C. (edited by). Planning Support Tools: Policy Analysis, Implementation and Evaluation. vol. chap 5, p. 489-500, MILANO: Franco Angeli, 2012

[28] Casarotto A., De Guio A., Ferrarese F., Action Gis: un modello predittivo del movimento antropico in un paesaggio antico. Il caso di studio della Val d'Alpone (VR), in Archeologia e Calcolatori n. 20, 2009, p. 301 